\title{
KEKERASAN DALAM MEDIA MASSA SEBAGAI CONTOH BENTUK PENDIDIKAN DISKRIMINATIF TERHADAP PEREMPUAN
}

\author{
Hj. Elfi mu'awanah, M.Pd
}

\begin{abstract}
Violence on mass media is one short of discrimination towards women. It shows the fact that violence which are mostly women experiencing needs real solution such as gender issues and regulation on domestic violence socialization. Government plays important part in reducing the rate of domestic violence that are presented in mass media lately in terms of law enforcement. It is also crucial that all people are aware of this issue if they become the victims report to institution or person who is in charge with domestic violence case.
\end{abstract}

\section{A. PENDAHULUAN}

Media massa telah berperan dalam mengkontruksi bias gender pada salah satu jenis kelamin terutama perempuan. Hal ini dapat dilihat pada tayangan televisi sebagian pelaku kekerasan adalah laki-laki dan korbannya sebagian besar adalah perempuan. Penyebab utama kekerasan yang terjadi adalah bias gender diantaranya karena munculnya steriotype kepada perempuan yang dipandang lemah sehingga dapat diperlakukan secara lemah oleh lelaki, atau sebagai istri bleh semena-mena diperlakukan tak wajar oleh suami terlebih munculnya hegemoni lelaki terhadap perempuan.

Dalam UU no 23 tahun $2004^{\mathrm{i}}$ klasifikasi jenis kekerasan dibagi menjadi empat yaitu psikis, fisik, seksual dan penelantaran keluarga. Sementara dalam perepektif HAM kekerasan dibagi menjadi empat yaitu ekonomi, psikis, fisik dan seksual. Kekerasan sebagian besar berdampak pada kesehatan reproduksi perempuan yang semestinya mendapatkan perlidungan. Untuk itu jangan sampai kita menjadi pelaku atau sebagai korban untuk menciptakan kesetaraan dan keadilan gender. Adapun peta kekerasan di Indonesia dapat dilihat dalam Tabel 1. Tabl 1 Peta Kekerasan Terhadap Perempuan ${ }^{\text {ii }}$ 


\begin{tabular}{|c|c|c|c|c|}
\hline Aspek & $\begin{array}{c}\text { Relasi } \\
\text { Personal }\end{array}$ & $\begin{array}{l}\text { Relasi } \\
\text { Kerja }\end{array}$ & $\begin{array}{c}\text { Relasi } \\
\text { Kemasyarakatan }\end{array}$ & Situasi Konflik \\
\hline BENTUK & $\begin{array}{l}\text { Tekanan } \\
\text { psikologis } \\
\text { Kekerasan fisik } \\
\text { Pelecehan } \\
\text { seksual } \\
\text { Perkosaan } \\
\text { Eksploitasi } \\
\text { ekonomi } \\
\text { Pekerja } \\
\text { keluarga } \\
\text { Bentuk-bentuk } \\
\text { deprevasi } \\
\text { penghalangan } \\
\text { pemenuhan } \\
\text { kebutuhan }\end{array}$ & 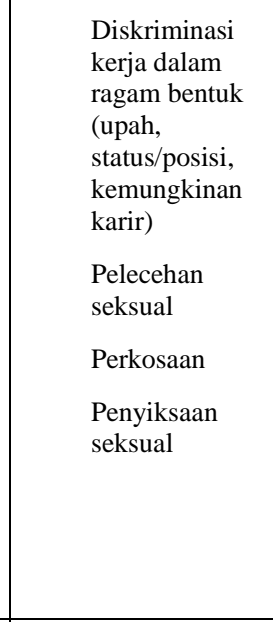 & $\begin{array}{l}\text { Pelecehan seksual } \\
\text { Perkosaan } \\
\text { Praktik-praktik } \\
\text { budaya (misalnya } \\
\text { ketiadaan hak } \\
\text { waris, } \\
\text { poligami/perceraian } \\
\text { sewenang-wenang, } \\
\text { pemotongan jari- } \\
\text { suku Dani) } \\
\text { Perdagangan } \\
\text { perempuan } \\
\text { Pornografi }\end{array}$ & \\
\hline LOKASI & $\begin{array}{l}\text { Rumah tinggal (dan } \\
\text { tempat lain yang } \\
\text { memungkinkan) }\end{array}$ & $\begin{array}{l}\text { Tempat kerja (dan } \\
\text { tempat lain yang } \\
\text { memungkinkan) }\end{array}$ & $\begin{array}{l}\text { Komunitas } \\
\text { Tempat umum } \\
\text { Tempat penampungan }\end{array}$ & $\begin{array}{l}\text { Tempat umum } \\
\text { Markas tentara } \\
\text { Rumah korban } \\
\text { Tempat pengungsian }\end{array}$ \\
\hline PELAKU & $\begin{array}{l}\text { Suami/mantan ayah } \\
\text { (kandung/tiri) } \\
\text { Saudara laki-laki } \\
\text { Pacar } \\
\text { Anggota keluarga lain/ } \\
\text { yang memiliki relasi } \\
\text { personal }\end{array}$ & $\begin{array}{l}\text { Majikan/ mandor } \\
\text { Sesama pekerja }\end{array}$ & Warga masyarakat & $\begin{array}{l}\text { Tentara } \\
\text { Sipil bersenjata } \\
\text { Orang yang memiliki } \\
\text { hubungan keluarga/ } \\
\text { relasi personal }\end{array}$ \\
\hline KORBAN & $\begin{array}{l}\text { Isteri } \\
\text { Anak perempuan } \\
\text { Perempuan dengan } \\
\text { status pacar, tunangan, } \\
\text { teman }\end{array}$ & $\begin{array}{l}\text { Pekerja sector informal } \\
\text { Pekerja sector formal } \\
\text { TKW } \\
\text { Pembantu rumah } \\
\text { tangga dan pekerja } \\
\text { rumahan lain } \\
\text { Aktivis buruh }\end{array}$ & $\begin{array}{l}\text { Perempuan dewasa } \\
\text { Perempuan dibawah umur } \\
\text { Anak jalanan }\end{array}$ & $\begin{array}{l}\text { Perempuan warga sipil } \\
\text { Perempuan pengungsi } \\
\text { Perempuan tahanan }\end{array}$ \\
\hline
\end{tabular}

\section{B. PEMBAHASAN}

Adapun dalam prespektif media, terutama dari televisi yang menayangkan program informasi, hiburan ataupun sinetron, diangkat dari kisah nyata ataupun imajinasi sebagian besar menggambarkan adanya kekerasan yang bias gender sebagai penyebab. 
Diantara contoh gambaran kekerasan yang ditayangkan dalam televisi adalah sebagai berikut.

1. Stasiun TV yang menayangkan Indosiar, judul tayangan : Chanda, waktu tayang pkl 09.00-30.00 tahunm 2005, waktu tayang 30 menit, bentuk kekerasan adalah pemaksaan kepada istrinya untuk melakukan dan mengerjakan seluruh pekerjaan rumah tangga yang diikuti dengan bentuk kekerasan psikologis sehingga menyebabkan tekanan yang luar biasa baik secara rohani seperti selalu mencari-cari kesalahan istri agar mudah bagi suami untuk melampiaskan kemarahannya. Perempuan disekap oleh suaminya di rumah dan tidak boleh keluar. Kekerasan fisik dilakukan berupa pemukulan dimana karena sebab istri tidak bisa mengerjakan perkerjaan rumah tangga karena memang istri mengalami keterbelakangan mental. Contohya ketika istri mengepel tempat yang sudah dibersihkan, si suami menaruh kotoran ditempat tersebut sehingga ada alasan memukul istri yang ridak bersih mengepel. Frekeuensi kejadian kekerasan hampir setiap hari, pelaku kekerasan adalah suami (Darius) didukung ibunya, sementara korban ekekerasan adalah Istri (Chanda).

Analisis dalam prespektif gender terhadap kejadian dalam sinetron tersebut adalah karena penyebab kekerasan adalah karena perempuan selalu diposisikan oleh suami sebagai orang yang lemah dan dianggap wajib melakukan semua pekerjaan domestik (rumah tangga) dan perempuan karenanya hanya pantas di rumah saja terlebih si istri adalah seorang yang mengalami keterbelakangan mental. Disamping itu perempuan diposisikan oleh suami bahwa ia makhluk penuh dengan kekurangan dan tidak mempunyai kelebihan kecuali hanya memberatkan dan merepotkan suami saja.

Apa yang terjadi pada sinetron dapat juga terjadi di masayarakat nyata, karena bisa jadi sinetron itu diilhami oleh kehidupan nyata. Tetapi apapun itu telah turut menjustifikasi seorang lelaki melakukan kekerasan terhadap istri. Atau masyarakat akan menilai bahwa apa yang dilakukan oleh suami kepada istrinya adalah kewajaran semata. Hal inilah yang semestinya diluruskan. 
Apapun tindak kekerasan telah melanggar hak asasi manusia perempuan, yaitu hak untuk bebas dari kekerasan. Dan sebagi korban dapat melaporkan kejadian tersebut kepada pihak kepolisian. Dan bahkan selama 1 x 24 jam kepolisian wajib memberikan perlindungan sementara ${ }^{\text {iii }}$ dan meneruskan laporan sesuai hukum yang berlaku. Dan setiap orang yang mendengar, melihat atau mengetahui kejadian tersebut wajibmelakukan upaya sesuai batas kemampuan untuk a) mencegah berlangsungnya tindak pidna, b) memberikan perlindungan kepada korban, c) memberikan pertolngan darurat, dan d) membantu proses pengajuan permohonan penetapan perlindungan ${ }^{\text {iv }}$. Bagan 1 menjelaskan bias Gender dalam Sinetron Chanda.

Bagan 1. Bias Gender Dalam Sinetron Chanda

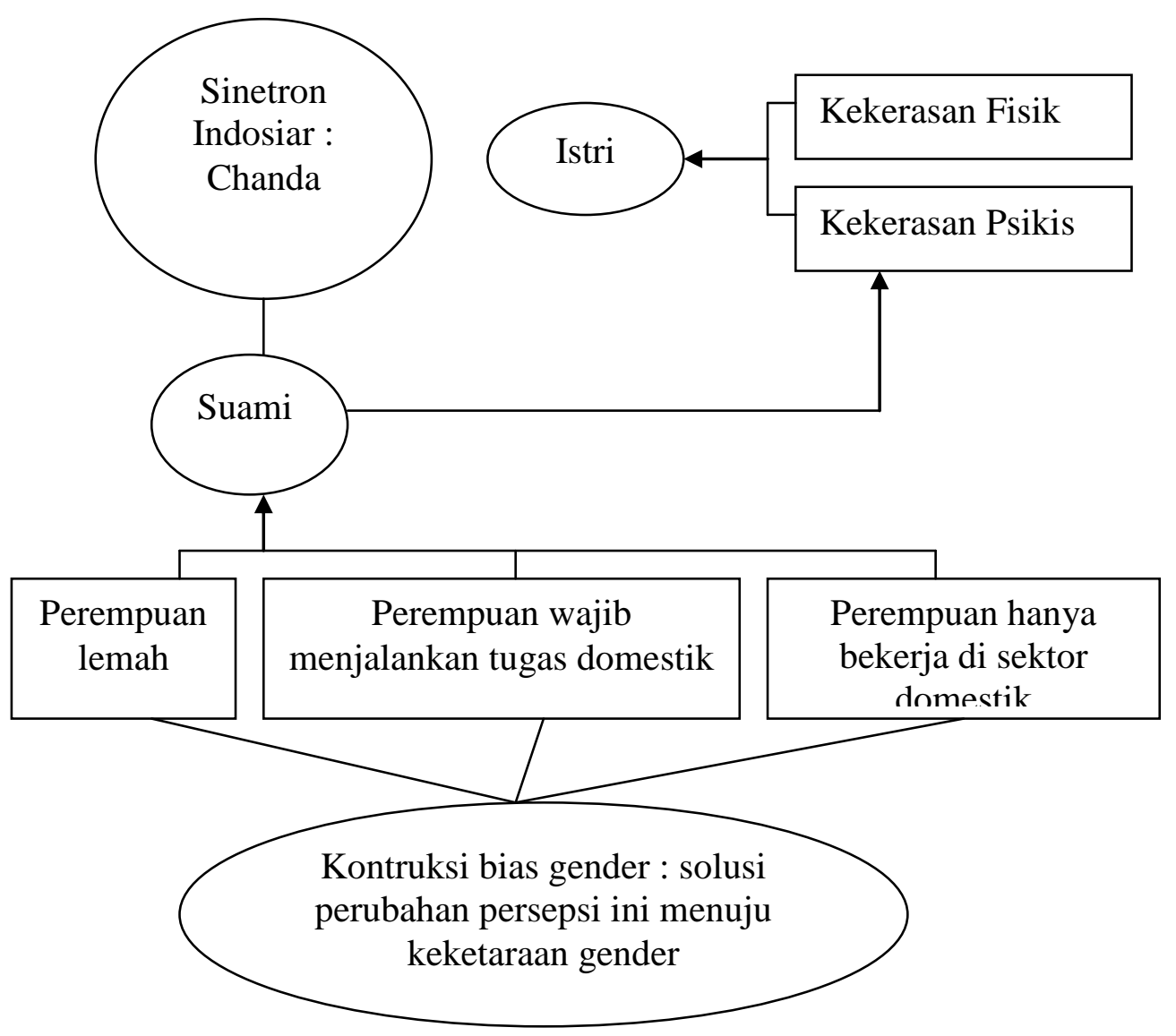

2. Stasiun TV yang menayangkan adalah SCTV,judul tayangan Derap Hukum, waktu tayang 9 April 2005 pkl 21.30 selama 30 menit, bentuk kekerasan adalah pemerkosaan, penganiayaan. Kronologisnya adalah 
Tarmas berusia 35 tahun memiliki kebiasaan mabuk meski sudah berkeluarga setua hari ada seorang gadis 15 tahun, berniat mencari air di sungai sekalian buang air. Pada waktu malam pkl 22.30 Tarman pulang dari warung dengan kondisi setengah mabuk melihat gadis buang air, timbul sahwatnya. Tanpa basa basi Tarman langsung menubruk gadis dan menyetubuhinya, gadis tak berdaya dan setelah disetubui kemudian dibunuh untuk menghilangkan jejak. Frekuensi kekerasan satu kali pembunuhan dan pemerkosaan, pelaku seorang lelaki (tetangga), korban adalah seorang perempuan.

Analisis berbasis gender adalah bahwa kekerasan terjadi karena perempuan masih dianggap selalu sebagai obyek pemuas seks, perempuan keluar malam dianggap salah karena memang tidak ada perlindungan perempuan yang keluar waktu malam.

3. Statiun Tv yang menayangkan adalah SCTV, judul tayangan derap hukum, waktu tayang pkl 21.30-22.00 bentuk kekerasan adalah pembunuhan dan perselingkuhan, peristiwanya adalah berawal dari pertengkaran yang sering terjadi antara suami-istri baik dari segi materi maupun non materi. Si suami tidak pernah memberikan nafkah kepada istrinya dan dia juga selingkuh dengan tetangganya yang sudah janda. Dari peristiwa pembunuhan ini terjadi pada suatu malam ketika suami istri mulai bertengkar. Suami meninggalkan rumah dan istri menduga suaminya ada di rumah janda tersebut. Lalu sang istri menyusul suaminya dan ternyata sedang membonceng janda tersebut dengan sepeda motor. Lalu istri bertengkar dengan janda tersebut, dan suami memukul istri dengan batu mengakibatkan meninggal. Frekuensi kekerasan berungkali berupa perselingkuhan dan pembunuhan satu kali. Pelaku kekerasan adalah suami, korban adalah istri. Analisis berbasis gender adalah suami istri mempunyai hak dan kewajiban masing-masing. Tetapi si suami merasa sebagai kepala keluarga berhak atas apa saja terhadap istrinya. Istri tidak diberi nafkah juga mengalah sementara suami malah semena-mena kepada istrinya dan nafkah malah diberikan pada orang lain. Ketiak branian istri menuntuk 
haknya pada suaminya juga menjadi berulangnya frekuensi kekerasan yang dilakukan suami kepada istrinya yaitu berupa perselingkuhan. Dan suami merasa selingkuh adalah hal wajar. Semstinya perselingkuhan merupakan kekerasan psikologis dan istri harus bebas dari kekerasan ini. Bias gender juga muncul ketika istri justru bertengakar dengan janda karena dianggap yang bersalah adalah janda. Semestinya si suami yang disalahkan dalam perselingkuhan ini. Ia tidak melaksankan kewajiban kepada istri malah memlih orang lain untuk ditanggugjawabi. Dari kasus ini maka dapat digambarkan kesimpulannya sebagaimana Bagan 2 berikut.

Bagan 2. Kekerasan Berbasis Gender

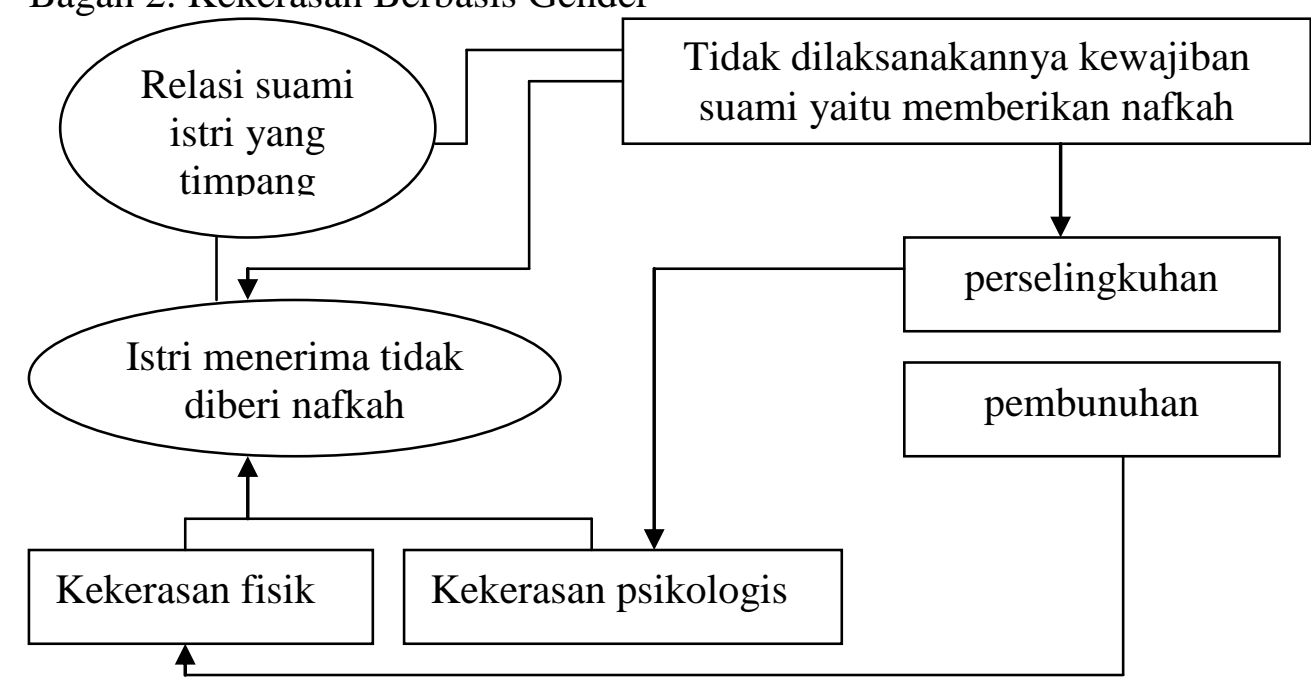

Dengan demikian solusinya adalah bahwa kewajiban suami memberikan nafkah kepada istri haruslah dipenuhi baik nafkah lahir mapun bathin bukan pada perempuan lain. Sementara istri wajib menuntut hal tersebut. Suami wajib menyadari kedudukan dan kewajibanya tersebut sementara si istri juga memiliki kewajiban dan hak yang juga harus diketahui dan dijalankan. Setiap orang harus bebas dari kekerasan baik di dalam rumah tangga maupun di luar rumah tangga.

4. Statiun TV yang menayangkan adalah Indosiar, judul tayangan adalah jejak kasus, waktu tayang pkl 12.00-12.30 selama 30 menit. Bentuk kekerasan, perkosaan dan pembunuhan. Kronologisnya adalah ketika seorang yeni mempunyai pacar Gibaldi, ia sedang mengandung anaknya dan ketika menutut Gibaldi untuk menikahinya Gibaldi menolak, tetapi 
yang terjadi malah justru yeni dibunuh oleh pacarnya. Pelaku kekerasan adalah seorang pacar (lelaki), korban adalah perempuan. Analisis dalam prespektif gender adalah bahwa perempuan lemah maka mudah untuk diperdaya. Kehamilan yang dialami adalah bentuk kekerasan seksual, meskipun suka-sama suka tetapi perempuan tetap sebagai korban, dan mestinya tidak ada hubungan seks sebelum menikah, karena bagaimanapun perempuan akan selalu dirugikan, tidak diketahui hak perempuan dalam masa pacaran merupakan penyebab menerimanya Yeni atas perlakuan pacarnya tersebut, yaitu persetubuhan sebelum menikah. Apapun yang dilakukan lelaki (pacar) ia telah melakukan kekerasan seksual, psikis dan fisik karenanya ia harus mendapatkan hukuman penjara sesuai ketentuan yang berlaku ${ }^{\mathrm{v}}$.

5. Stasiun yang menayangkan RCTI, judul tayangan Silet, waktu tayang pkl 11.00-11.30 pada 13 April 2005 hari Rabo, bentuk kkerasan adalah Fisik yaitu penamparan, pelemparan benda kerasa karena apa yang dilakukan tidak sesuai dengan suami, disamping itu juga kekerasan psikis yaitu dihina, dicemooh karena perempuan gemuk, terlebih juga ada kekerasan ekonomi yaitu diminta suaminya untuk bekerja sementara uang dikuasai dirinya sendiri. Frekuensi terjadinya kekerasan adalah sering sekali, pelaku kekerasan adalah suami, dan korban kekerasan adalah istri (Huges). Selanjutnya kesimpulan kekerasan ini dapat digambarkan dalam Bagan 3. 
Bagan 3. Kekerasan Fisik, Ekonomi dan Psikis

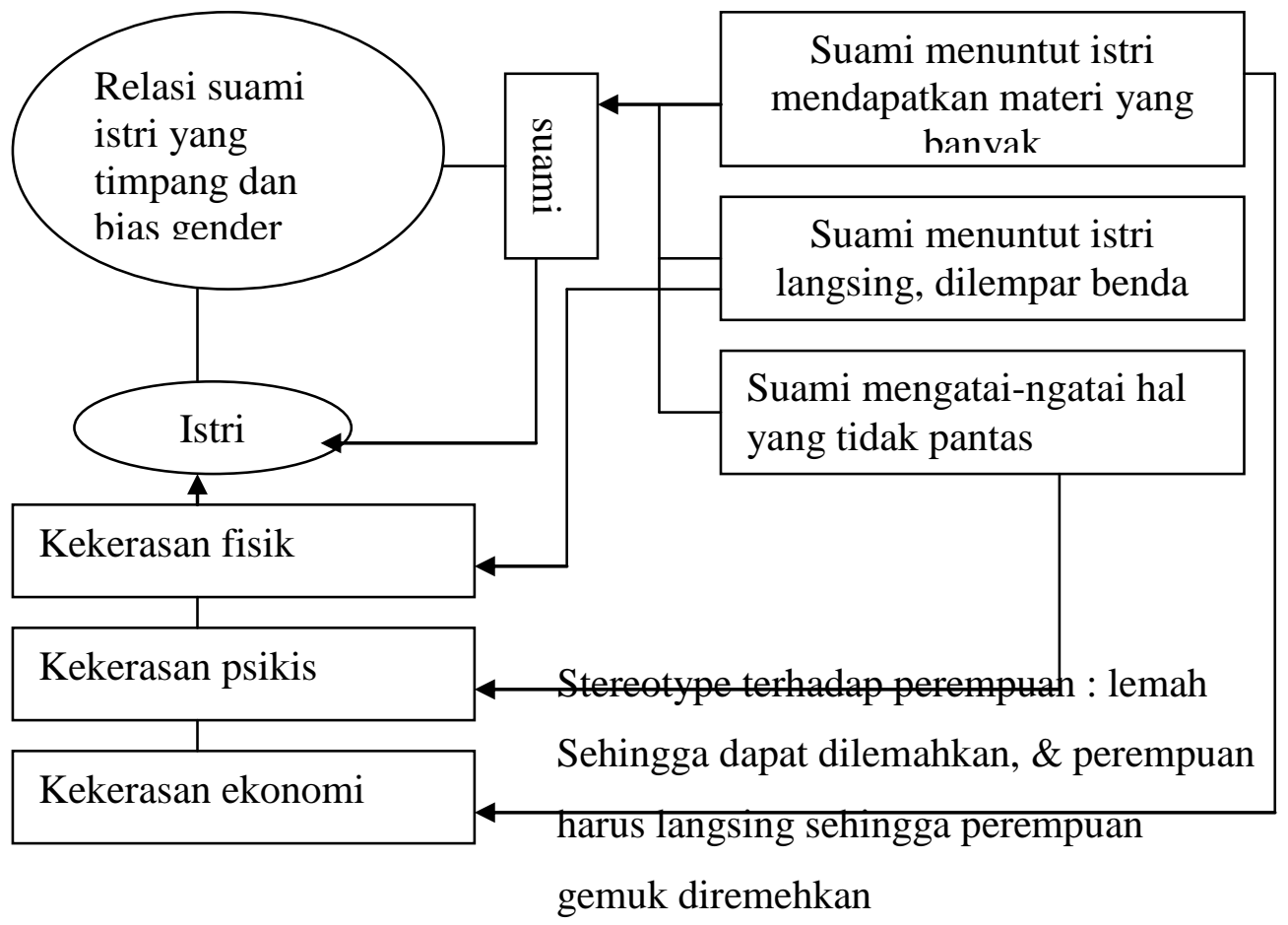

\section{PENUTUP}

Melihat 5 kasus kekerasan yang ditayangkan televisi sebagai sample dari sekian banyak kerasan yang menimpa perempuan adalah bebasis gender, maka usaha untuk mengurangi kekerasan tersebut adalah dengan menghilangkan bias gender untuk menciptakan kesetaraan dan keadilan gender. Pemahaman atas hak dan kewajiban dalam rumah tangga bagi masing-masing pasangan, pekerjaan domestik dilakukan bersama pasangan adalah sebagai bagian yang dapat dilakukan oleh semua pihak.

Sementara konteks Islam terdapat ketentuantentang kekerasan yang pada hakekatnya merupakan tindakan yang harus dihindari. Adapun klasifikasi kekerasan dapat dilihat indikasinya melalui ungkapan tentang:

1. Kekerasan fisik, seperti menampar, menganiaya secara fisik sebagaimana dalam Quran Surat berikut.

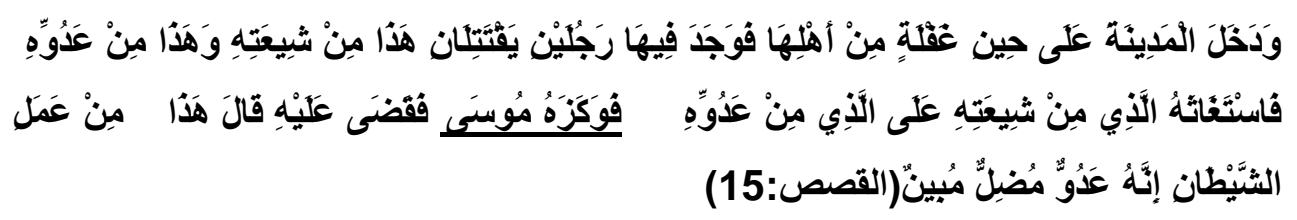


Artinya: Dan Musa masuk ke kota (Memphis) ketika penduduknya sedang lengah, maka didapatinya di dalam kota itu dua orang laki-laki yang berkelahi; yang seorang dari golongannya (Bani Israil) dan seorang (lagi) dari musuhnya (kaum Fir`aun). Maka orang yang dari golongannya meminta pertolongan kepadanya, untuk mengalahkan orang yang dari musuhnya lalu Musa meninjunya, dan matilah musuhnya itu. Musa berkata: "Ini adalah perbuatan syaitan sesungguhnya syaitan itu adalah musuh yang menyesatkan lagi nyata (permusuhannya) (QS. Qhashah (28): 15)

2. Kekerasan Psikologis, seperti bersikap menyakiti hati orang lain, menceritakan kabar bohong, meneror yang dapat merendahkan harga diri sebagaimana ungkapan Quran Surat dan Hdist berikut.

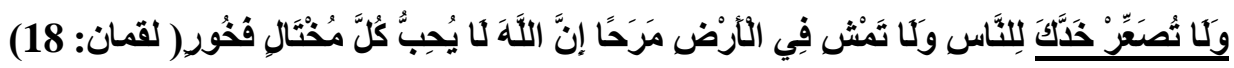
Artinya: Dan janganlah kamu memalingkan mukamu dari manusia (karena sombong) dan janganlah kamu berjalan di muka bumi dengan angkuh. Sesungguhnya Allah tidak menyukai orang-orang yang sombong lagi membanggakan diri (QS. Luqman (31);18)

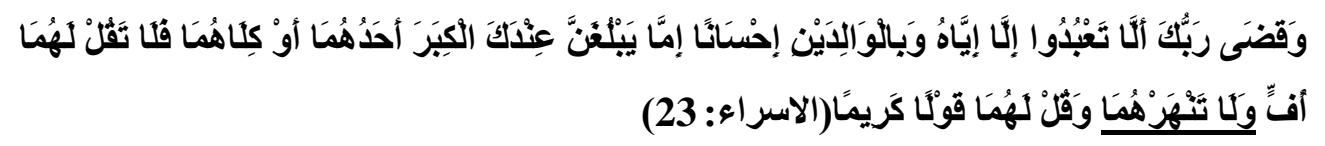

Artinya: Dan Tuhanmu telah memerintahkan supaya kamu jangan menyembah selain Dia dan hendaklah kamu berbuat baik pada ibu bapakmu dengan sebaik-baiknya. Jika salah seorang di antara keduanya atau keduaduanya sampai berumur lanjut dalam pemeliharaanmu, maka sekali-kali janganlah kamu mengatakan kepada keduanya perkataan "ah" dan janganlah kamu membentak mereka dan ucapkanlah kepada mereka perkataan yang mulia . (QS. Al-Israa' (17): 23).

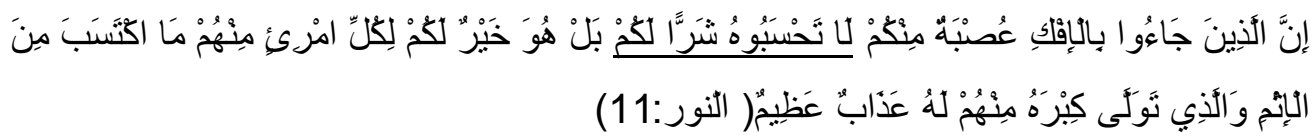

Artinya: Sesungguhnya orang-orang yang membawa berita bohong itu adalah dari golongan kamu juga. Janganlah kamu kira bahwa berita bohong itu buruk 
bagi kamu bahkan ia adalah baik bagi kamu. Tiap-tiap seseorang dari mereka mendapat balasan dari dosa yang dikerjakannya. Dan siapa di antara mereka yang mengambil bahagian yang terbesar dalam penyiaran berita bohong itu baginya azab yang besar (QS. An-Nuur :11)

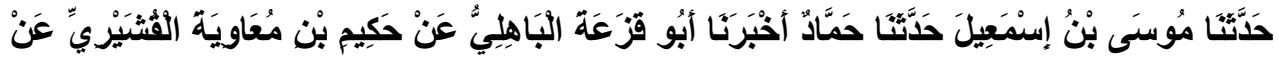

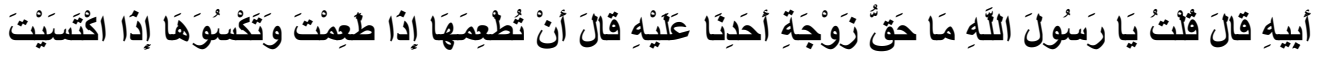

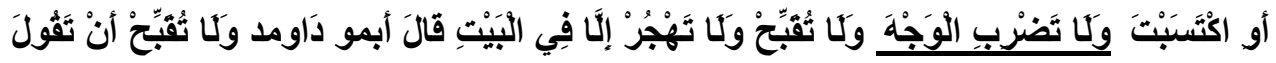
قبََّّكَ اللَهُ (سننى ابى داود)

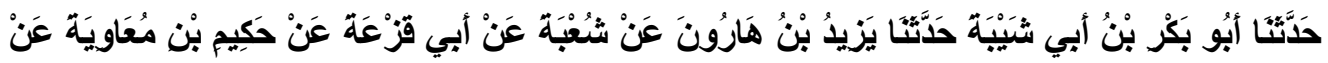

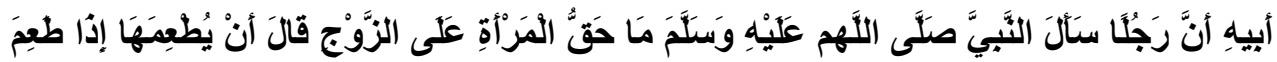

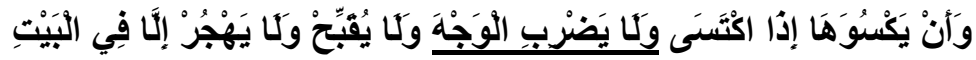

(رواه (بن ما جه)

3. Kekerasan seksual, berupa perselingkuhan atau "menggoda" bukan pada pasangan atau pelecehan seksual dapatdilihat dalam Quran Surat berikut:

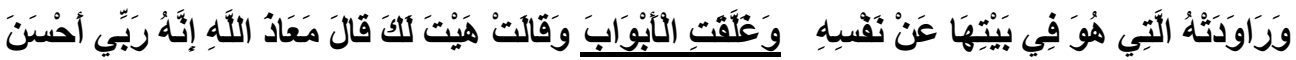

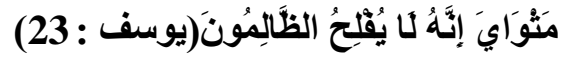

Artinya: Dan wanita (Zulaikha) yang Yusuf tinggal di rumahnya menggoda Yusuf untuk menundukkan dirinya (kepadanya) dan dia menutup pintu-pintu, seraya berkata: "Marilah kesini." Yusuf berkata: "Aku berlindung kepada Allah, sungguh tuanku telah memperlakukan aku dengan baik." Sesungguhnya orang-orang yang zalim tiada akan beruntung (QS.Yusuf: 23)

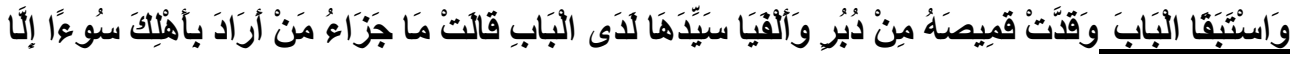

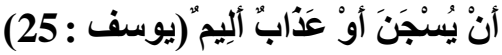

Artinya: Dan keduanya berlomba-lomba menuju pintu dan wanita itu menarik baju gamis Yusuf dari belakang hingga koyak dan kedua-duanya mendapati suami wanita itu di muka pintu. Wanita itu berkata: "Apakah pembalasan 
terhadap orang yang bermaksud berbuat serong dengan isterimu, selain dipenjarakan atau (dihukum) dengan azab yang pedih?" (QS.Yusuf: 25)

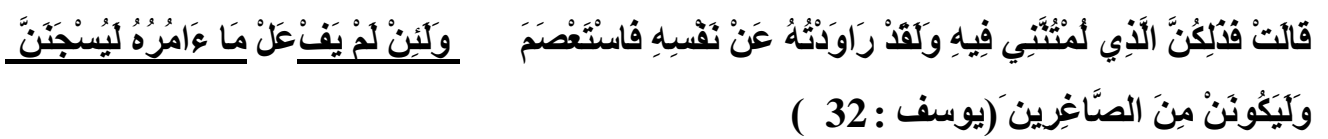

Artinya: Wanita itu berkata: "Itulah dia orang yang kamu cela aku karena (tertarik) kepadanya, dan sesungguhnya aku telah menggoda dia untuk menundukkan dirinya (kepadaku) akan tetapi dia menolak. Dan sesungguhnya jika dia tidak mentaati apa yang aku perintahkan kepadanya, niscaya dia akan dipenjarakan dan dia akan termasuk golongan orang-orang yang hina." (QS.Yusuf: 32)

4. Kekerasan ekonomi, yaitu berupa memakan harta yang bukan menjadi haknya, diantaranya dapat dilihat dalam Quran Surat berikut:

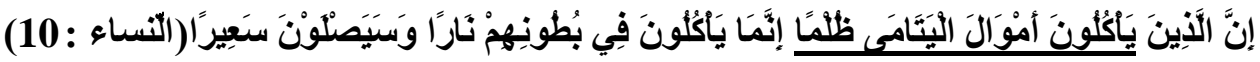
Artinya: Sesungguhnya orang-orang yang memakan harta anak yatim secara zalim, sebenarnya mereka itu menelan api sepenuh perutnya dan mereka akan masuk ke dalam api yang menyala-nyala (neraka) (QS. An-Nisaa'(4): 10).

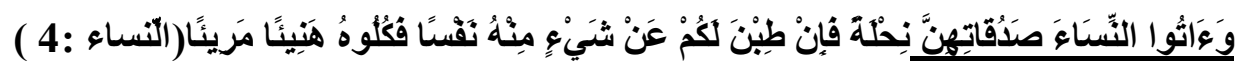

Artinya: Berikanlah maskawin (mahar) kepada wanita (yang kamu nikahi) sebagai pemberian dengan penuh kerelaan. Kemudian jika mereka menyerahkan kepada kamu sebagian dari maskawin itu dengan senang hati, maka makanlah (ambillah) pemberian itu (sebagai makanan) yang sedap lagi baik akibatnya (QS. An-Nisaa'(4): 4).

Bahwa kekerasan fisik, psikologis, seksual dan ekonomi dalam ajaran Islam hendaknya merupakan tindakan yang sejauh mungkin harus dihindari karena merugikan orang lain. Apaun alasannya kekerasan yang dilakukan akan mendapatkan hukuman yang setimpal. 


\section{BIBLIOGRAFI}

Undang-Undang Republik Indonesia Nomor 23 Tahun 2004 tentang Penghapusan Kekerasan Dalam Rumah Tangga pada Bab III tentang larangan Kekerasan Dalam Rumah Tangga pasal 5.

Sumber : Komnas Perempuan, "Peta Kekerasan : Pengalaman Perempuan Indonesia (SGIFF-CIDA, The Asia Foundation dan Yayasan TIFA, 2002).

Undang-Undang Republik Indonesia Nomor 23 Tahun 2004 tentang Penghapusan Kekerasan Dalam Rumah Tangga pada pasal 16.

Undang-Undang Republik Indonesia Nomor 23 Tahun 2004 tentang Penghapusan Kekerasan Dalam Rumah Tangga pasal 15

Undang-Undang Republik Indonesia Nomor 23 Tahun 2004 tentang Penghapusan Kekerasan Dalam Rumah Tangga tentang Ketentuan Pidana kekerasan Fisik yaitu hukuman 4 bulan s/d 15 tahun atau denda 5 juta s/d 25 juta (pasal 44) kekerasan Psikis yaitu hukuman 4 bulan -3 tahun atau denda 3 juta s/d 9 juta (pasal 45) kekerasan seksual yaitu hukuman 4 tahun s/d 20 tahun atau denda 15 juta s/d 500 juta (pasal 46, 47, 48) dan kekerasan penelantaran keluarga yaitu hukuman 3 tahun atau denda 15 juta (pasal 49) 